Metals and Ceramics Division

\title{
Oxidation of Mo-41Re at Low Oxygen Pressures: 2000 Status Report
}

\author{
J. R. DiStefano and L. D. Chitwood
}

Date Published: October 2000

Prepared for the

U. S. Department of Energy

Office of Space and Defense Power Systems

\author{
Prepared by the \\ OAK RIDGE NATIONAL LABORATORY \\ Oak Ridge, Tennessee 37831-6285 \\ operated by \\ UT-Battelle, LLC \\ for the \\ U.S. DEPARTMENT OF ENERGY \\ under contract DE-AC05-00OR22725
}





\section{CONTENTS}

Page

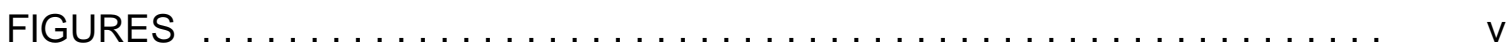

ABSTRACT $\ldots \ldots \ldots \ldots \ldots \ldots \ldots \ldots \ldots \ldots \ldots \ldots \ldots \ldots \ldots \ldots \ldots \ldots \ldots \ldots$

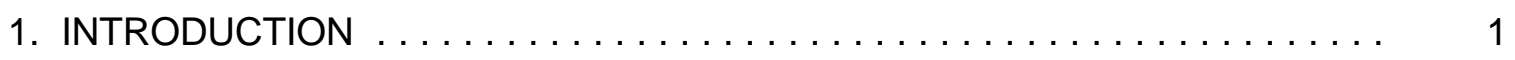

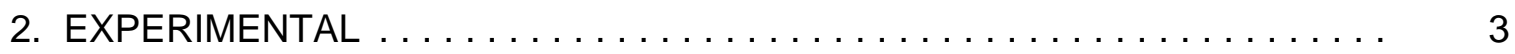

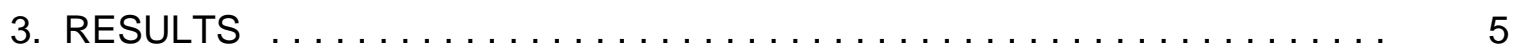

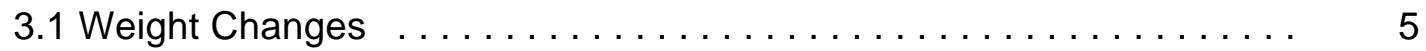

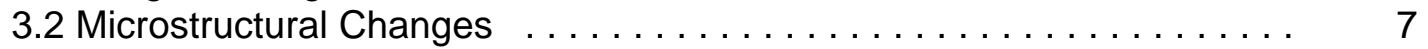

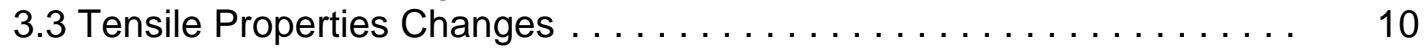

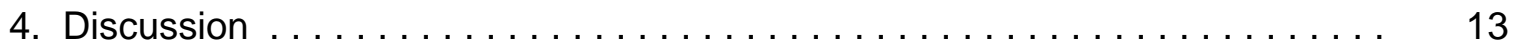

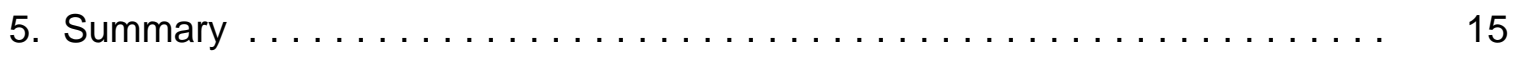

ACKNOWLEDGMENTS $\ldots \ldots \ldots \ldots \ldots \ldots \ldots \ldots \ldots \ldots \ldots \ldots \ldots \ldots$

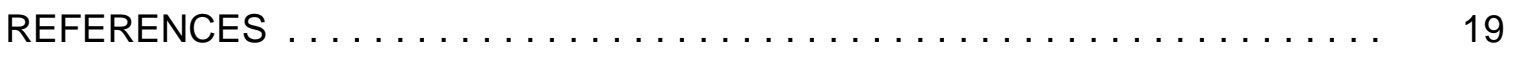





\section{FIGURES}

Figure

Page

1. Plot of weight change rate versus temperature at several partial pressures of oxygen

2. Weight change rate versus oxygen partial pressure at temperatures from $600-900^{\circ} \mathrm{C}$

3. Weight change rate versus temperature in argon containing 5 wppm oxygen $\left(10\right.$ wppm for test at $\left.1100^{\circ} \mathrm{C}\right) \ldots \ldots \ldots \ldots \ldots$

4. Mo-41Re sample after oxidation in argon-5 wppm $\mathrm{O}_{2}$ for $100 \mathrm{~h}$ at $900^{\circ} \mathrm{C}$

5. Duplex reaction layers on Mo-41Re after oxidation $\ldots \ldots \ldots \ldots \ldots \ldots$

6. Reaction zone in Mo-41Re exposed to argon-10 wppm oxygen for $500 \mathrm{~h}$ at $1100^{\circ} \mathrm{C} \ldots \ldots \ldots \ldots \ldots \ldots \ldots \ldots \ldots \ldots \ldots \ldots \ldots \ldots \ldots \ldots \ldots$

7. Growth of reaction zone during oxidation in argon at $900^{\circ} \mathrm{C} \ldots \ldots \ldots$ 



\section{TABLES}

Table

Page

1. Microprobe results of Mo-41Re sample after oxidation in argon-10 wppm oxygen for $500 \mathrm{~h}$ at $1100^{\circ} \mathrm{C}$

2. Tensile properties of Mo-41Re after oxidation 



\begin{abstract}
Rhenium generally improves the properties of molybdenum, and, therefore, there is interest in use of Mo-Re alloys in space system applications. Both Mo and $\mathrm{Re}$ have relatively low solubilities for oxygen but readily form oxide scales when exposed to oxidizing environments above $\sim 350^{\circ} \mathrm{C}$. Studies are being conducted on Mo-41Re to determine the rate of oxidation, type of scale formation, and effects on mechanical properties as a function of temperature and partial pressure of oxygen. Thus far, weight gains associated with formation of $\mathrm{MoO}_{2}$ have been found for $\mathrm{Po}_{2}<10^{-3} \mathrm{~Pa}$ (torr) in vacuum, and weight losses associated with evaporation of $\mathrm{MoO}_{3}$ above $10^{-3} \mathrm{~Pa}$. However, no significant changes in tensile properties were measured.
\end{abstract}





\section{INTRODUCTION}

Alloys of Mo-Re have the potential for structural use in space systems because of their excellent high temperature strength and corrosion resistance to liquid alkali metals. Although Re does not affect the already good corrosion resistance of unalloyed Mo, the addition of Re does enhance strength, ductility, and fabricability, especially, with respect to welding. In general, refractory metals and alloys all have significant high temperature strength, but they do not have satisfactory oxidation resistance at temperatures above $300-400^{\circ} \mathrm{C}$. Some refractory metals ( $\mathrm{Nb}, \mathrm{Ta}$, e.g.) have relatively high oxygen solubilities, and they often readily embrittle due to internal oxidation. $^{1,2}$ However, Mo, Re, and $\mathrm{W}$ have low oxygen solubilities and form surface oxide scales at the onset of oxidation, even at relatively low oxygen partial pressures. However, there are few quantitative data on oxidation rate as a function of pressure and temperature and the subsequent effect on mechanical properties under these conditions. 



\section{EXPERIMENTAL}

Mo-41Re (wt\%) tensile samples were stamped from arc cast sheet material that was fabricated at ORNL. The subsized tensile samples are the SS-3 design used for measuring tensile properties after irradiation. These tensile specimens have a $1.5 \mathrm{~mm} \times 7.6 \mathrm{~mm}$ long gage section and are $\sim 0.5 \mathrm{~mm}$ thick. Prior to oxidation the samples were annealed for $2 \mathrm{~h}$ at $1400^{\circ} \mathrm{C}$ in vacuum. Oxidation tests at low oxygen partial pressure in vacuum were conducted by first evacuating the system to a low base pressure $\left(\sim 10^{-6} \mathrm{~Pa}\right)$ and then, while the system is still being pumped, opening a micrometering valve to admit either pure oxygen or argon containing a known concentration of oxygen until the desired pressure is achieved. Tests were also conducted in argon ( $5 \mathrm{vppm}$ oxygen) at 1 atmosphere. After evacuating the system, the vacuum valve was closed and the test system pressurized to 1 atmosphere. Excess pressure was relieved through an oil bubbler.

Weight changes were measured after oxidation and selected samples were characterized metallographically and for changes in tensile properties. 



\section{RESULTS}

\subsection{Weight Changes}

Results from exposure to pure oxygen at reduced oxygen pressures are shown in Fig. 1. At $10^{-3}-10^{-4} \mathrm{~Pa}\left(10^{-5}-10^{-6}\right.$ torr $)$ small weight gains were observed after $500 \mathrm{~h}$ that generally increased with temperature. However at $10^{-2} \mathrm{~Pa}\left(10^{-4}\right.$ torr) weight losses were measured that became significantly larger at $800-900^{\circ} \mathrm{C}$. In Fig. 2, the weight change rate after $500 \mathrm{~h}$ exposures is shown as a function of $\mathrm{Po}_{2}$. Weight gains were measured at all temperatures below $\sim 1 \times 10^{-5} \mathrm{~Pa}\left(10^{-3}\right.$ torr $)$, but as was indicated in Fig.

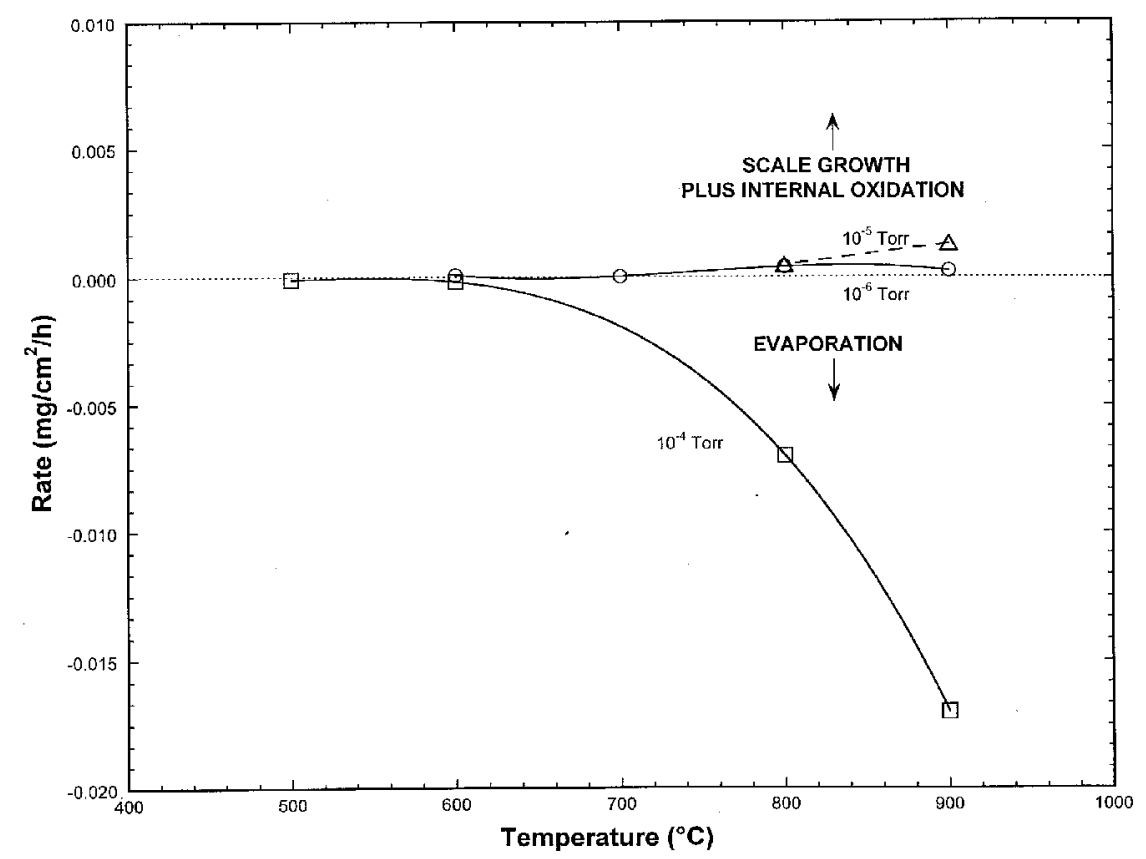

Fig. 1. Plot of weight change rate $(500 \mathrm{~h})$ versus temperature at several partial pressures of oxygen.

1 weight losses occurred at higher pressures.

Results in argon (1 atm) are shown in Fig. 2 and Fig. 3. In contrast with the results in vacuum, weight gains were measured at the higher temperatures and only at $600^{\circ} \mathrm{C}$ was a weight loss measured. 


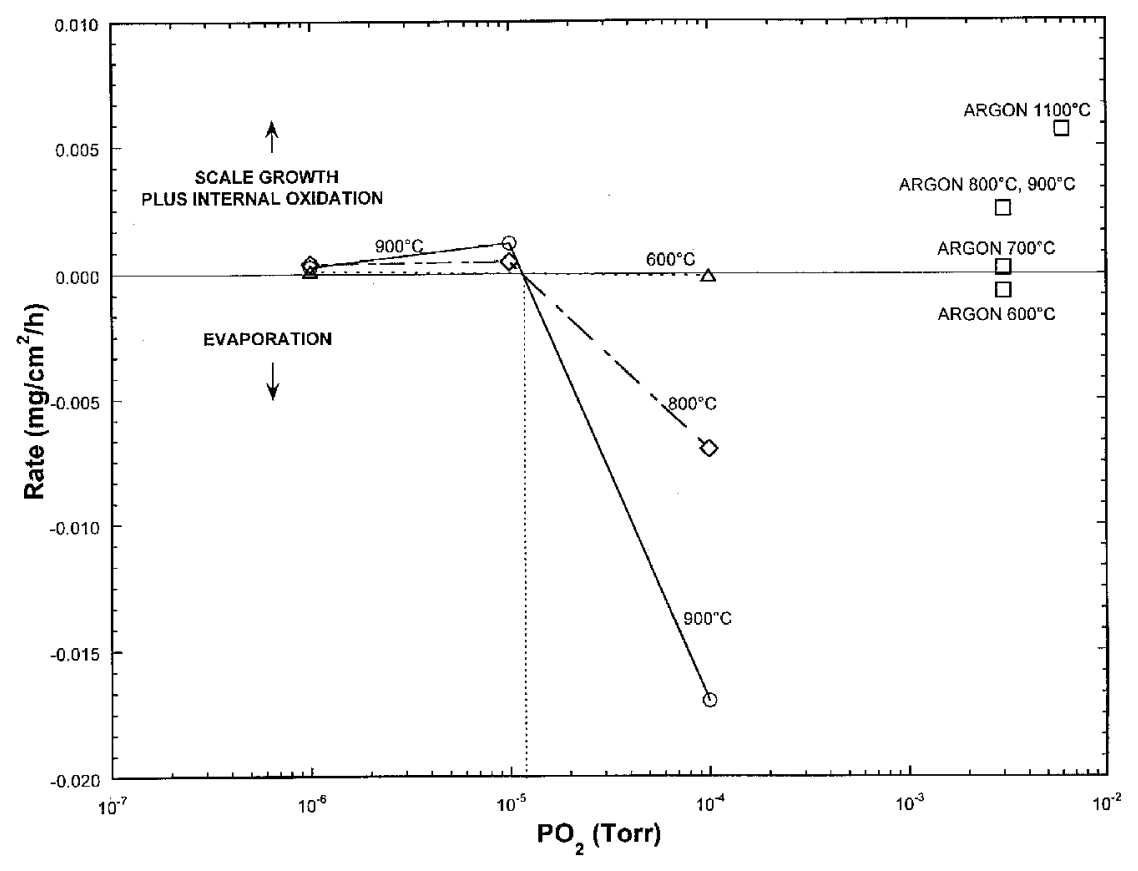

Fig. 2. Weight change rate (500 h) versus oxygen partial pressure at temperatures from $600-900^{\circ} \mathrm{C}$.

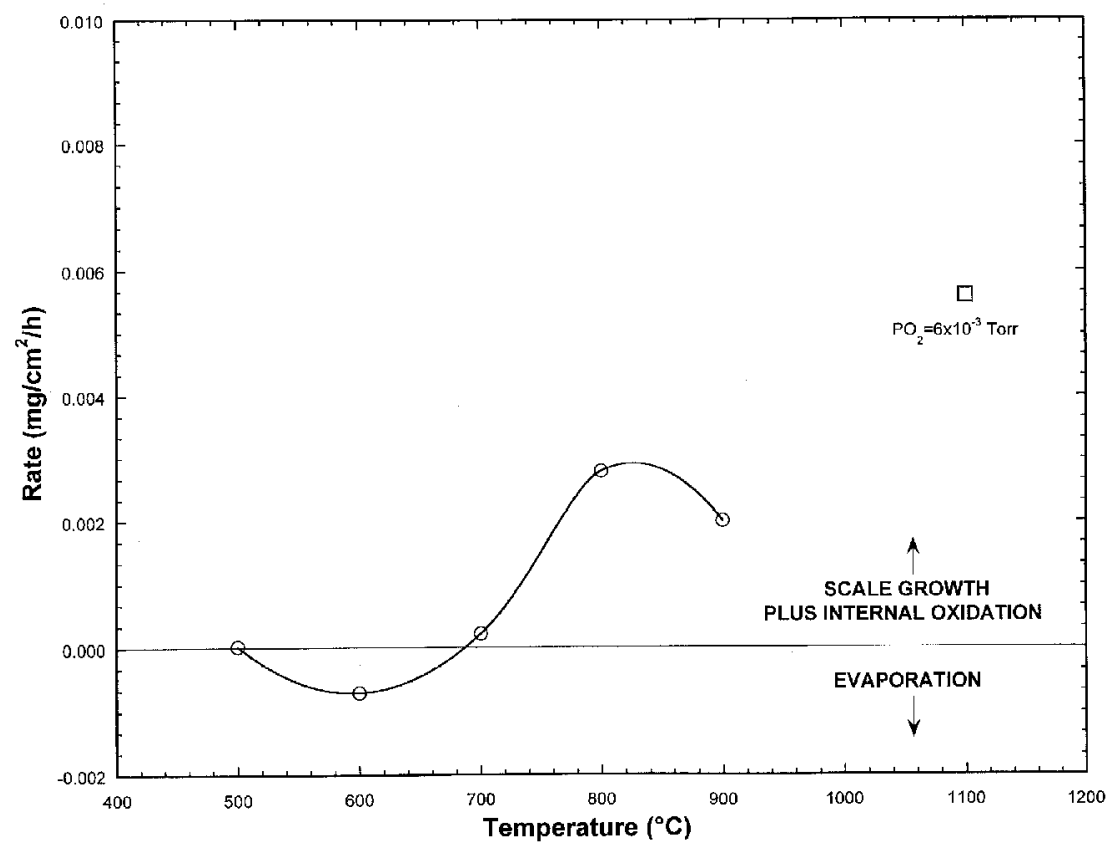

Fig. 3. Weight change rate $(500 \mathrm{~h})$ versus temperature in argon containing 5 wppm oxygen (10 wppm for test at $\left.1100^{\circ} \mathrm{C}\right)$. 


\subsection{Microstructural Changes}

The surface and grain structure of Mo-41Re after annealing $2 \mathrm{~h}$ at $1400^{\circ} \mathrm{C}$ followed by exposure to argon $\left(5 \mathrm{O}_{2}-15 \mathrm{~N}_{2}\right)$ for $100 \mathrm{~h}$ at $900^{\circ} \mathrm{C}$ is shown in Fig. 4 . Under these conditions the sample picked-up 200 wppm oxygen and there was little change observed microstructurally. However, after longer times a surface layer and a subsurface, duplex reaction zone developed as shown in Fig. 5. X-ray and microprobe analyses identified the outer layer as $\mathrm{MoO}_{2}$, but the reaction zone beneath the $\mathrm{MoO}_{2}$ was fine-structured and difficult to analyze precisely. Microprobe analysis of a sample exposed at $1100^{\circ} \mathrm{C}$ indicated the reaction zone beneath the $\mathrm{MoO}_{2}$ contained several different compositions of Mo, Re, and $\mathrm{O}$ (Fig. 6 and Table 1). It is likely that this region also contains $\mathrm{MoO}_{2}$ since it was very hard ( 1375 DPH), together with Mo-Re alloy. In one analysis (Position 3), the Re content was above that in the base alloy, an indication that some depletion of $\mathrm{Mo}$ occurred due to formation of $\mathrm{MoO}_{2}$. It must be remembered, however, that the analyses are dependent on which phases and how much of each are included in the microprobe spot size. In Fig. 7, a plot of weight change versus time is shown along with the depths of the outer and inner reaction zones. Note that the growth of the outer and inner reaction zones occur at approximately the same rates at $900^{\circ} \mathrm{C}$.

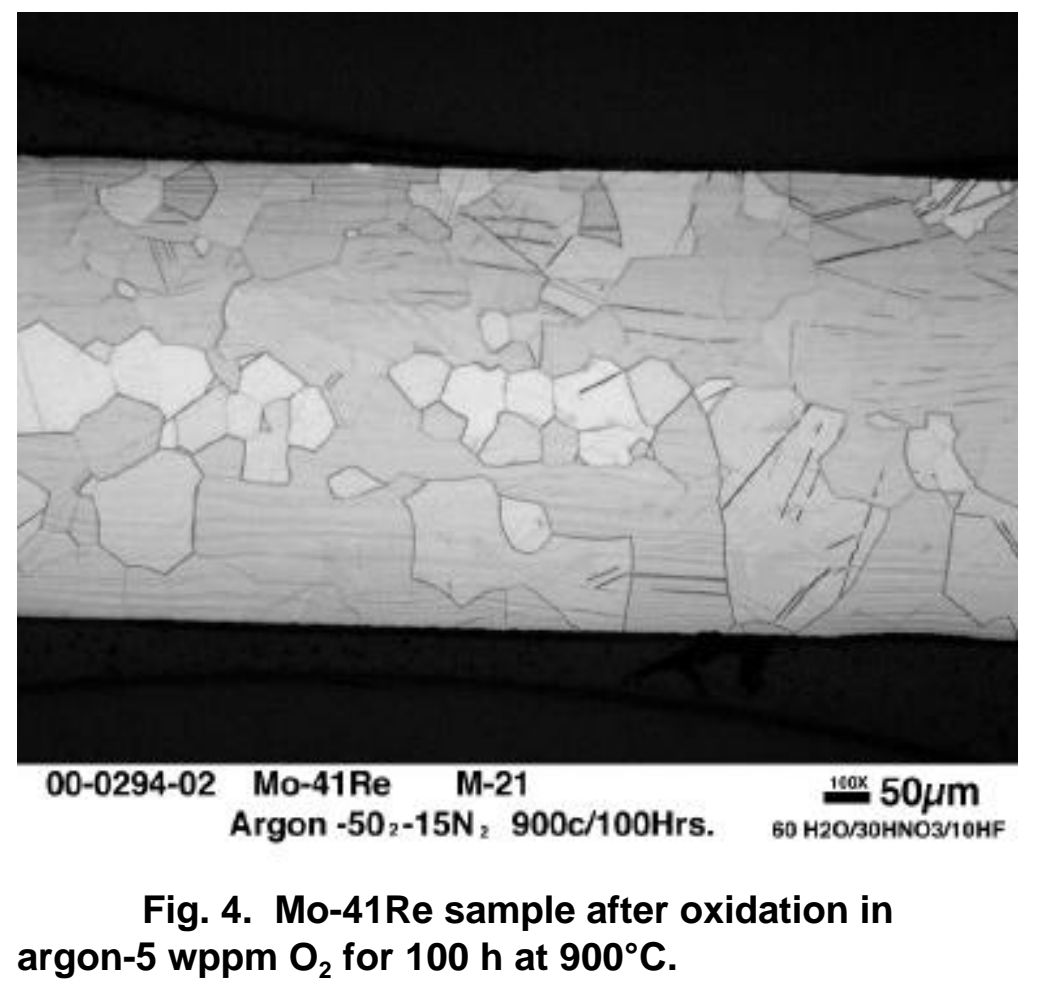




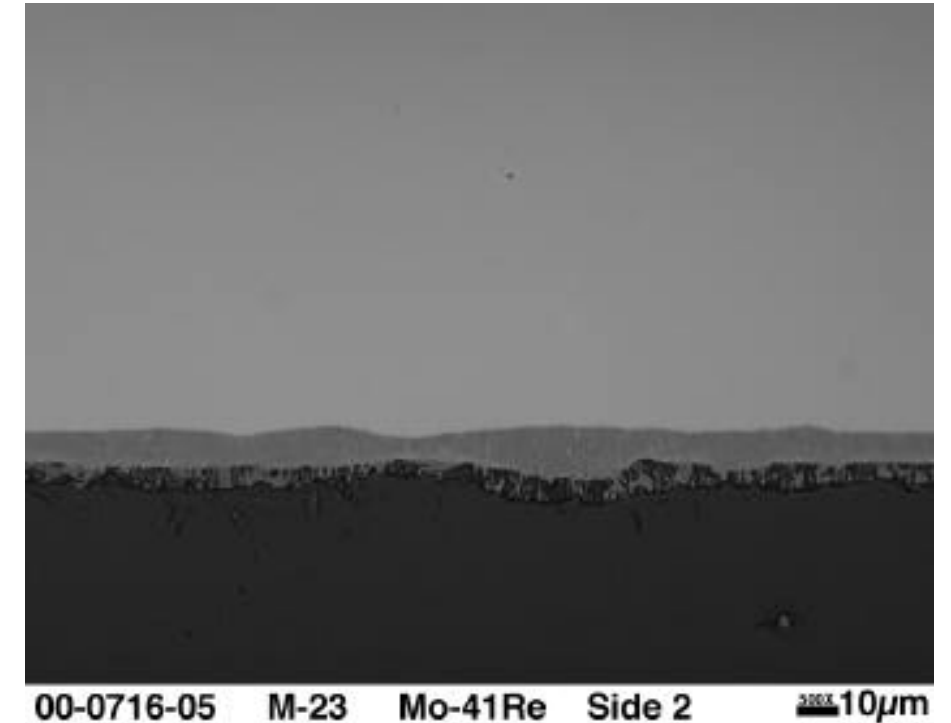

Argon $/ 900^{\circ} \mathrm{C} / 1000 \mathrm{~h} / 1 \mathrm{~atm}+10,861 \mathrm{ppm}^{\text {As pollshed }}$

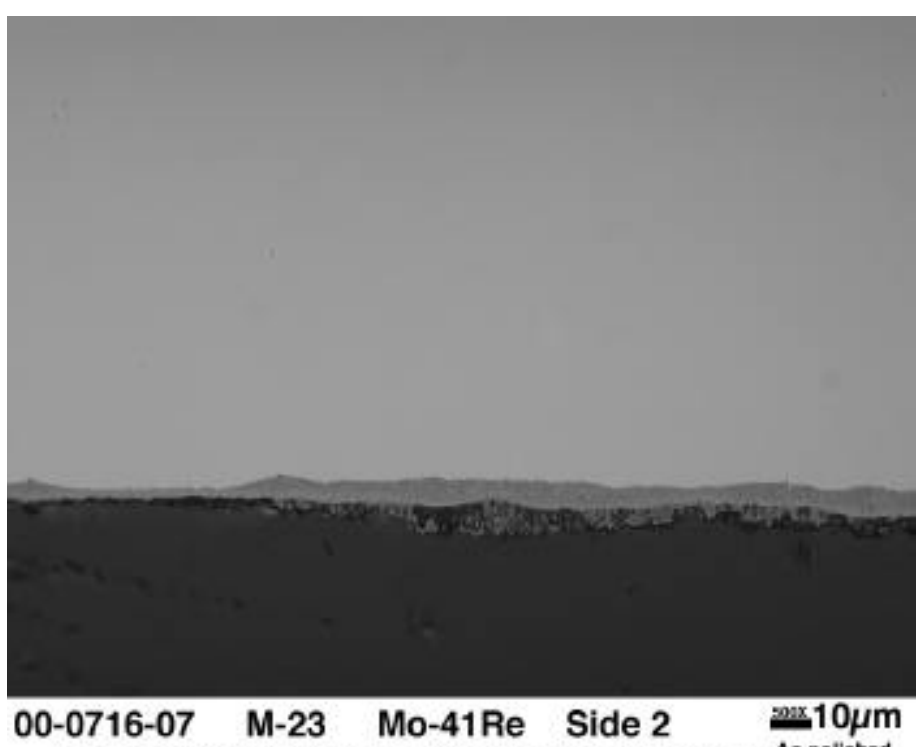

00-0716-07 M-23 Mo-41Re Side 2 and $10 \mu \mathrm{m}$ Argon $/ 900^{\circ} \mathrm{C} / 1000 \mathrm{~h} / 1 \mathrm{~atm}+10,861 \mathrm{ppm}^{\text {As polished }}$
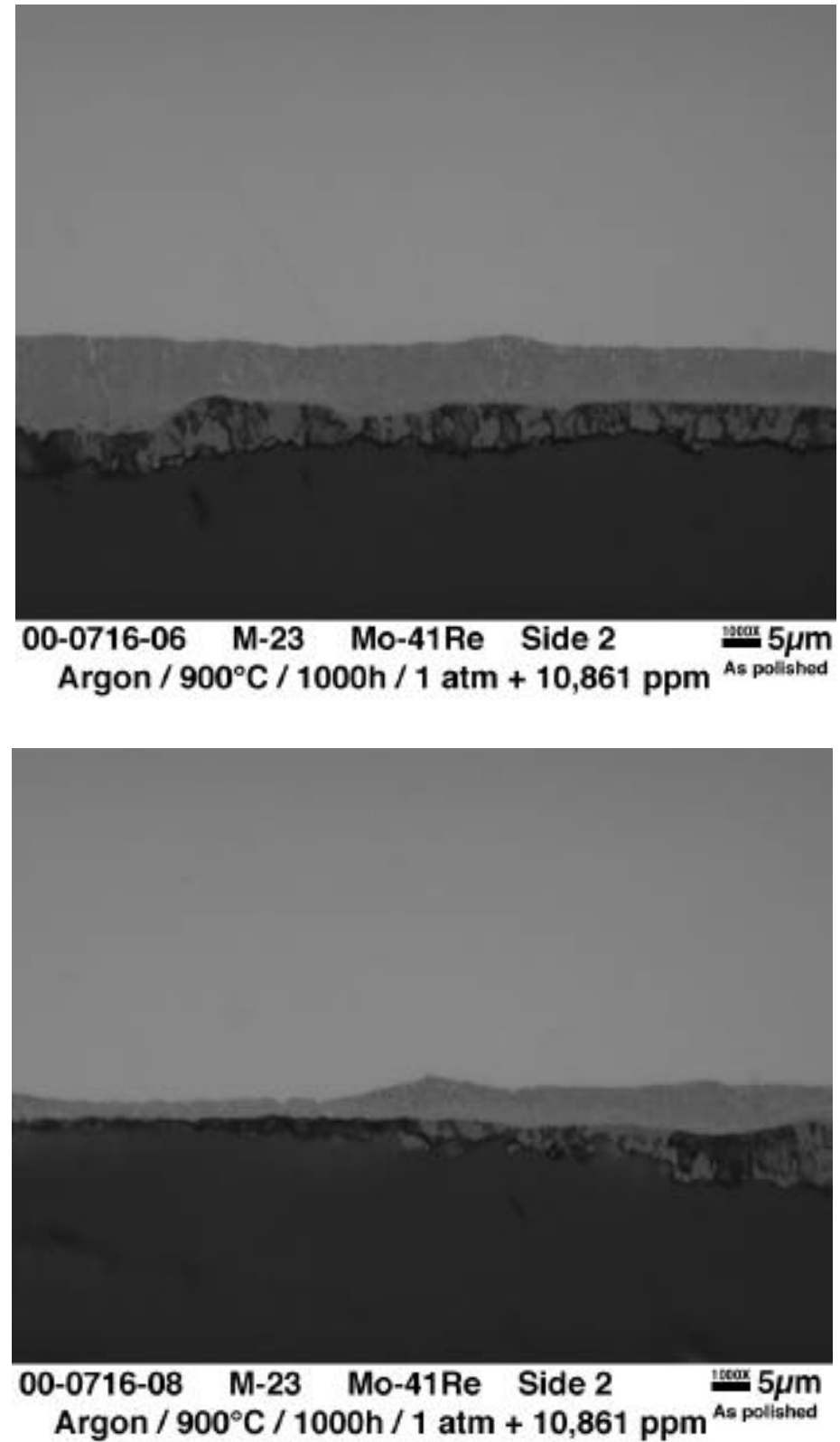

Fig. 5. Duplex reaction layers on Mo-41Re after oxidation. 


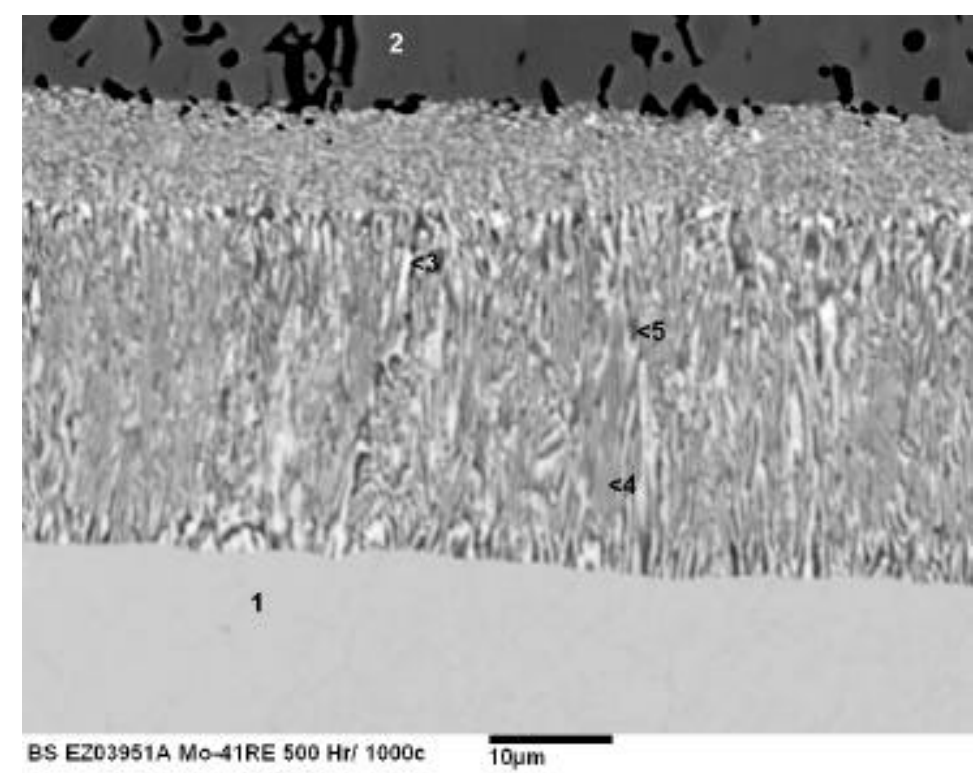

Fig. 6. Reaction zone in Mo-41Re exposed to argon-10 wppm oxygen for $500 \mathrm{~h}$ at $1100^{\circ} \mathrm{C}$.

Table 1. Microprobe results of Mo-41Re sample after oxidation in argon-10 wppm oxygen for $500 \mathrm{~h}$ at $1100^{\circ} \mathrm{C}$

\begin{tabular}{|c|c|c|c|c|c|c|c|}
\hline \multicolumn{5}{|c|}{ Element Wt \% } & \multicolumn{3}{|c|}{ At. \% - Normalized } \\
\hline Quantity \# & Mo & $\mathrm{Re}$ & $\mathrm{O}$ & Total & Mo & $\mathrm{Re}$ & $\mathrm{O}$ \\
\hline \multicolumn{8}{|c|}{ Position 1 (base metal) } \\
\hline 1 & 60.1 & 41.5 & 0.0 & 101.6 & 73.8 & 26.2 & 0.0 \\
\hline 2 & 60.0 & 41.4 & 0.0 & 101.4 & 73.7 & 26.3 & 0.0 \\
\hline 3 & 60.3 & 40.8 & 0.0 & 101.1 & 74.2 & 25.8 & 0.0 \\
\hline \multicolumn{8}{|c|}{ Position 2 (outer layer) } \\
\hline 4 & 74.7 & 0.6 & 26.7 & 102.1 & 31.7 & 0.1 & 68.1 \\
\hline 5 & 74.7 & 0.5 & 26.6 & 101.8 & 31.9 & 0.1 & 68.0 \\
\hline 6 & 74.5 & 0.4 & 26.7 & 101.6 & 31.7 & 0.1 & 68.2 \\
\hline \multicolumn{8}{|c|}{ Position 3 (inner oxidation region) } \\
\hline 7 & 44.1 & 52.7 & 7.4 & 104.1 & 38.1 & 23.5 & 38.4 \\
\hline 8 & 39.8 & 54.1 & 8.1 & 102.0 & 34.2 & 23.9 & 41.9 \\
\hline 9 & 34.9 & 61.2 & 6.8 & 102.8 & 32.6 & 29.4 & 38.0 \\
\hline 10 & 48.6 & 44.7 & 8.8 & 102.0 & 39.1 & 18.5 & 42.4 \\
\hline 11 & 43.4 & 52.0 & 4.2 & 99.6 & 45.7 & 28.2 & 26.2 \\
\hline \multicolumn{8}{|c|}{ Position 4 (inner oxidation region) } \\
\hline 12 & 46.6 & 41.6 & 13.7 & 101.9 & 31.0 & 14.3 & 54.8 \\
\hline 13 & 53.3 & 36.3 & 14.7 & 104.3 & 33.3 & 11.7 & 55.0 \\
\hline 14 & 50.2 & 40.5 & 11.4 & 102.1 & 36.1 & 15.0 & 48.9 \\
\hline 15 & 51.5 & 38.5 & 13.3 & 103.2 & 34.1 & 13.1 & 52.7 \\
\hline \multicolumn{8}{|c|}{ Position 5 (inner oxidation region) } \\
\hline 16 & 62.4 & 17.7 & 21.2 & 101.3 & 31.4 & 4.6 & 64.0 \\
\hline 17 & 58.2 & 24.3 & 21.5 & 104.0 & 29.1 & 6.3 & 64.6 \\
\hline 18 & 63.9 & 17.3 & 22.5 & 103.7 & 30.8 & 4.3 & 64.9 \\
\hline 19 & 56.6 & 28.5 & 19.6 & 104.7 & 30.0 & 7.8 & 62.2 \\
\hline
\end{tabular}




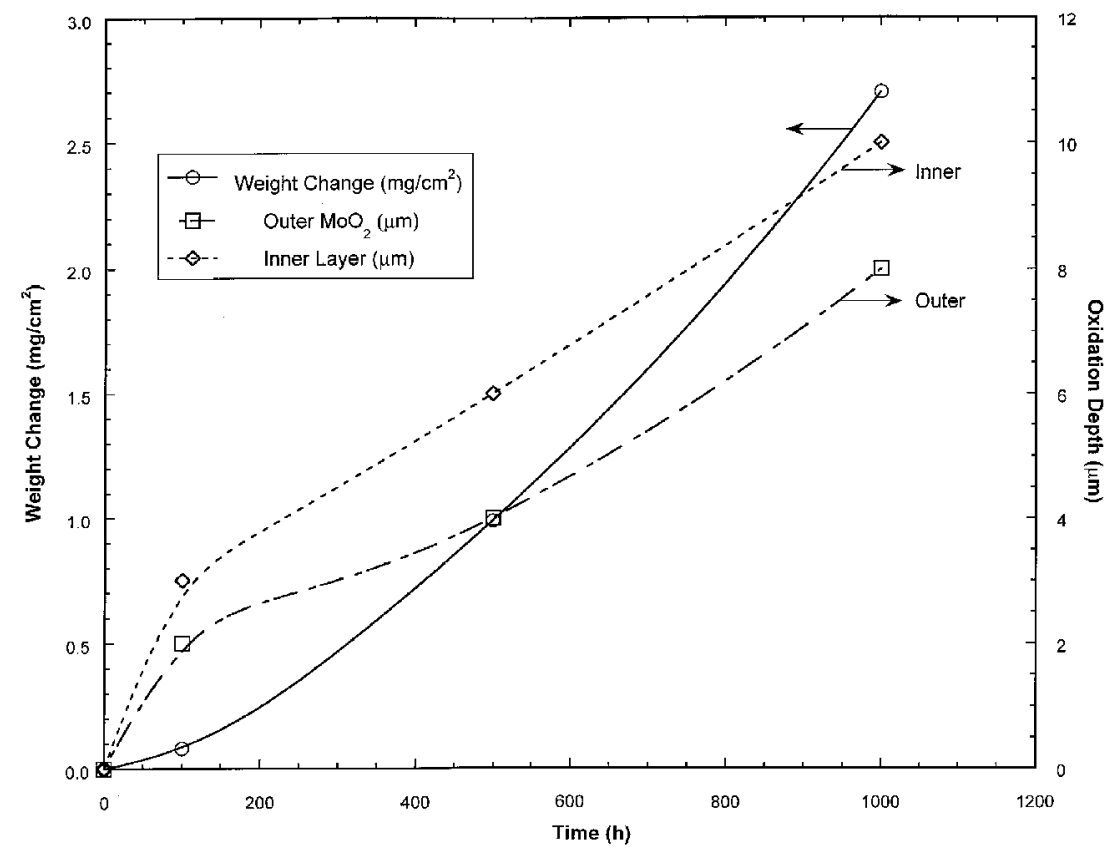

Fig. 7. Growth of reaction zone during oxidation in argon at $900^{\circ} \mathrm{C}$.

\subsection{Tensile Properties Changes}

Tensile properties of selected Mo-41Re samples were measured after oxidation either at room temperature or at the oxidation temperature. Variations in yield and ultimate tensile strength were generally within one standard deviation after test, but the samples tested at room temperature and $650^{\circ} \mathrm{C}$ were slightly weaker after oxidation compared with an unoxidized sample as shown in Table 2. Note that this did not occur at $900^{\circ} \mathrm{C}$ and the tensile data did not show any significant variation after oxidation. Elongation, a measure of the material's ductility, was relatively unchanged at each temperature. After oxidation that produced a weight increase of $>1 \%$, room temperature tensile properties were not significantly different from samples showing either a small weight increase or decrease. At $900^{\circ} \mathrm{C}$, the same type of behavior was found for a weight decrease of $1.5 \%$. Thus, weight changes that result in relatively thin layers of $\mathrm{MoO}_{2}$ or small losses due to evaporation of $\mathrm{MoO}_{3}$ do not appear to significantly affect the tensile properties of Mo-41Re. 
Table 2. Tensile properties of Mo-41Re after oxidation

\begin{tabular}{|c|c|c|c|c|c|c|}
\hline $\begin{array}{c}\text { Sample } \\
\text { number }\end{array}$ & wppm & $\begin{array}{c}\text { Tensile test } \\
\text { temperature } \\
\left({ }^{\circ} \mathrm{C}\right)\end{array}$ & $\begin{array}{c}\text { YS } \\
(\mathrm{MPa})\end{array}$ & $\begin{array}{c}\text { UTS } \\
(\mathrm{MPa})\end{array}$ & $\begin{array}{c}\text { Uniform } \\
(\%) \\
\text { elongation }\end{array}$ & $\begin{array}{c}\text { Total } \\
(\%) \\
\text { elongation }\end{array}$ \\
\hline $\mathrm{M} 93$ & - & $\mathrm{RT}$ & 689 & 656 & 14 & 19 \\
\hline $\mathrm{M} 32$ & -322 & $\mathrm{RT}$ & 584 & 688 & 13 & 15 \\
\hline $\mathrm{M} 21$ & +322 & $\mathrm{RT}$ & 564 & 734 & 13 & 14 \\
\hline $\mathrm{M} 22$ & +310 & $\mathrm{RT}$ & 586 & 776 & 14 & 17 \\
\hline $\mathrm{M} 23$ & $+10,861$ & $\mathrm{RT}$ & 506 & 668 & 13 & 17 \\
\hline $\mathrm{M} 25$ & $+3,883$ & $\mathrm{RT}$ & 557 & 719 & 13 & 18 \\
\hline $\mathrm{M} 94$ & - & 650 & 339 & 517 & 15 & 28 \\
\hline $\mathrm{M} 13$ & +147 & 650 & 266 & 480 & 22 & 30 \\
\hline $\mathrm{M} 14$ & +167 & 650 & 258 & 468 & 20 & 26 \\
\hline $\mathrm{M} 16$ & $+4,614$ & 650 & 267 & 465 & 20 & 26 \\
\hline $\mathrm{M} 8$ & +217 & 850 & 464 & 505 & 19 & 26 \\
\hline $\mathrm{M} 9$ & +311 & 850 & 343 & 511 & 19 & 33 \\
\hline $\mathrm{M} 7$ & +500 & 850 & 350 & 538 & 19 & 34 \\
\hline $\mathrm{M} 11$ & - & 900 & 320 & 449 & 13 & 36 \\
\hline $\mathrm{M} 6$ & +159 & 900 & 339 & 457 & 17 & 36 \\
\hline $\mathrm{M} 5$ & +221 & 900 & 348 & 446 & 13 & 36 \\
\hline $\mathrm{M} 3$ & $-1.5 \%$ & 900 & 318 & 415 & 14 & 35 \\
\hline
\end{tabular}





\section{Discussion}

In vacuum, weight changes in Mo-41Re are a function of temperature and pressure. At $10^{-3}$ and $10^{-4} \mathrm{~Pa}\left(10^{-5}, 10^{-6}\right.$ torr $)$, the rate of weight increase was positive but very low to $900^{\circ} \mathrm{C}$. Above $10^{-3} \mathrm{~Pa}$ the weight change became negative. On the other hand, the thickness of the $\mathrm{MoO}_{2}$ layer is primarily a function of pressure. After exposure for $200 \mathrm{~h}$ at $10^{-4} \mathrm{~Pa}$ and $850^{\circ} \mathrm{C}$, the specimen had a weight gain and a $1.5 \mu \mathrm{m}$ thick $\mathrm{MoO}_{2}$ layer. But after exposure for $100 \mathrm{~h}$ at $3 \times 10^{-3} \mathrm{~Pa}$ at $900^{\circ} \mathrm{C}$, the specimen showed a weight loss but a $10 \mu \mathrm{moO}_{2}$ layer. In argon, weight changes were almost always gains even though the oxygen partial pressure was higher, and, at $900^{\circ} \mathrm{C}$ the growth of the oxide regions paralleled the weight increase. Weight changes are the net of the increase in $\mathrm{MoO}_{2}$ minus evaporation of $\mathrm{MoO}_{3}$, so it is difficult to determine whether oxidation is actually slowed in argon compared with vacuum or if evaporation is occurring. Nevertheless, it is very encouraging that relatively small amounts of weight increase due to oxide formation have relatively little effect on the mechanical properties of Mo-41Re. This seems to support the hypothesis that without internal oxidation, embrittlement is less likely. 



\section{Summary}

Studies were conducted to examine the oxidation behavior of Mo-41Re at reduced oxygen pressures $\left(10^{-3}-10^{-6}\right.$ torr range) as might occur in vacuum or argon environments that could be encountered during fabrication and testing of space system components. In vacuum, weight change rates were low below $\sim 600^{\circ} \mathrm{C}$ $\left(10^{-4}-10^{-5} \mathrm{mg} / \mathrm{cm}^{2} / \mathrm{h}\right)$. In general, low temperatures/pressures result in weight gains due to growth of $\mathrm{MoO}_{2}$ at the surface. Although weight gains generally increase with temperature, if the pressure of oxygen reaches a sufficient level, oxidation of $\mathrm{MoO}_{2}$ to $\mathrm{MoO}_{3}$ occurs which leads to weight losses from evaporation of $\mathrm{MoO}_{3}$ in the dynamic environment. Contrarily, in flowing argon (1 atm), weight increases continued to occur even at high temperatures/pressures. Significant weight changes, either gains or losses and in vacuum or argon, were characterized by formation of an external layer of $\mathrm{MoO}_{2}$ and a complex, hard, internal oxidation zone that consisted of several phases containing some combination of $\mathrm{Mo}, \mathrm{Re}$, and oxygen. Oxidation exposure generally resulted in no systematic change in tensile strength and ductility with growth of the oxidation zone.

Thus far the data indicate that dynamic vacuum environments containing oxygen partial pressures $\leq 10^{-4} \mathrm{~Pa}\left(10^{-6}\right.$ torr) would be required to limit Mo-41Re to small weight gains from oxidation at temperatures to $900^{\circ} \mathrm{C}$. If an argon environment is required, oxygen levels of 5-10 ppm are sufficient to cause a significant oxidation rate of this alloy at temperatures $\geq 800^{\circ} \mathrm{C}$. However, the effect of oxidation is either growth of a surface oxide, $\mathrm{MoO}_{2}$, or evaporation of $\mathrm{MoO}_{3}$. These effects should be considered with respect to any changes in properties required for a particular application, e.g., emittance or strength of thin sections. 



\section{ACKNOWLEDGMENTS}

The authors are indebted to J. P. Moore and J. F. King for their support of this work and review of the manuscript. We would also like to acknowledge the contribution of H. E. Longmire, J. R. Mayotte and L. R. Walker to the metallographic and microprobe analysis that was performed, and F. C. Stooksbury and K. A. Choudhury for preparation of the manuscript and figures. 



\section{REFERENCES}

1. L. J. Pionke and J. W. Davis, "Technical Assessment of Niobium Alloys Data Base for Fusion Applications,"McDonald Douglas Corporation, COO-4247-2, August 1979, p. 7.

2. J. R. DiStefano and J. H. DeVan, "Reactions of Oxygen with V-Cr-Ti Alloys," Journal of Nuclear Materials, 249 (1997) 150-158. 



\section{INTERNAL DISTRIBUTION}

1. E. E. Bloom

2. L. D. Chitwood

3. J. H. DeVan

4-8. J. R. DiStefano

9. J. F. King

10. E. T. Manneschmidt

11-12. J. P. Moore

13. A. E. Pasto
14. P. T. Tortorelli

15. K. E. Wilkes

16-17. Central Research Library

18. Document Reference Section

19-20. ORNL Laboratory Records-RC

21. Office of Scientific \& Technical Information

\section{EXTERNAL DISTRIBUTION}

22. R. W. Buckman, Refractory Metals Technology, P.O. Box 10055, Pleasant Hills, PA 15236

23. L. E. DeFillipo, Lockheed Martin Astronautics, 100-U8620, P.O. Box 8555, Philadelphia, PA 19101

24. S. R. Martin, Jr., DOE-ORO, Building 4500N, Mail Stop 6269, P.O. Box 2009, Oak Ridge, TN 37831

25. E. Mussi, Advanced Modular Power Systems, 4370 Varsity Drive, Ann Arbor, Ml 48108-2241

26-28. Office of Space and Defense Power Systems, NE-50, Germantown Building, U.S. Department of Energy, 19901 Germantown Road, Germantown, MD 20874-1290

R. R. Furlong

L. C. Herrera

A. S. Mehner 
